\title{
Very high-resolution mapping of emerging biogenic reefs using airborne optical imagery and neural network: the honeycomb worm (Sabellaria alveolata) case study
}

\author{
Collin Antoine ${ }^{1,2,{ }^{*}}$, Dubois Stanislas ${ }^{3}$, Ramambason Camille ${ }^{1}$, Etienne Samuel ${ }^{1}$
}

${ }^{1}$ Ecole Pratique des Hautes Etudes (EPHE), PSL Research University, Dinard, Brittany, France

${ }^{2}$ Laboratoire d'Excellence CORAIL, Perpignan, France

3 IFREMER, Laboratoire d'Ecologie Benthique Côtière (LEBCO), Plouzané, France

* Corresponding author : Antoine Collin, email address : antoine.collin@ephe.sorbonne.fr

\begin{abstract}
:
Biogenic reefs provide a wide spectrum of ecosystem functions and services, such as biodiversity hotspot, coastal protection, and fishing practices. Honeycomb worm (Sabellaria alveolata) reefs, in the Bay of Mont-Saint-Michel (France), constitute the largest intertidal bioconstruction in Europe but undergo anthropogenic pressures (aquaculture-stemmed food/space competition and siltation, fishingdriven trampling). Very high-resolution (VHR) airborne optical data enable cost-efficient biophysical measurements of reef colonies, strongly expected for conservation approaches. A synergy of remotely sensed airborne optical imagery, calibration/validation photoquadrat ground-truth (202/101, respectively), and artificial neural network (ANN) modelling is first used to map $S$. alveolata relative abundance, over the largest bioconstruction in Europe. The best prediction of $S$. alveolata abundance was reached with the infrared-red-green (IRRG) spectral combination and ANN model structured with six neurons $\left(R^{2}=0.72\right.$, RMSE $=0.08$, and $\left.r=0.85\right)$. The six hyperbolic tangent formulas were applied to the three input spectral bands (IRRG) in order to build six hidden neuronal images, resulting in VHR digital S. alveolata abundance model $(6547 \times 6566$ pixels with $0.5 \mathrm{~m}$ pixel size $)$. The innovative model revealed undescribed spatial patterns, namely a reef polarization (perpendicular to the shoreline) of $S$. alveolata abundance: high abundance on forereef and low abundance on backreef.
\end{abstract}




\section{Introduction}

27 Coastal reef builders are able to primarily shape the ecology of local environment 28 through the sediment reworking. By trapping and binding carbonate sands, some 29 cyanobacteria and diatoms produce the stromatolites (Andres and Reid 2006), crustose 30 coralline algae form coatings (Gherardi and Bosence 2001), molluscan vermetidae build 31 bioconstructions (Donnarumma et al. 2017), and cnidarian corals create large barriers 32 (Mumby et al. 2003). Less renown despite their very high productivity, annelids (i.e. 33 worms) can create substantial reefs along tropical and temperate coasts (terebellidae: 34 Degraer et al. 2008; serpulidae: Moore et al. 2009; and sabellariidae: Naylor and Viles 35 2000).

Honeycomb worm reefs erected by the gregarious tube-building polychaete Sabellaria alveolata (Linnaeus, 1767) in the megatidal Bay of Mont-Saint-Michel 38 (BMSM, France) consist of the largest intertidal bioconstruction in Europe (Noernberg 39 et al. 2010; Desroy et al. 2011). Contrary to more common encrusting veneers or 40 hummocks on rocky shores, the Sainte-Anne population in the BMSM develops on soft 41 sediment. It is currently structured as three extensive reef entities within the tidal flats. 42 Such biogenic reefs largely contributes to ecosystem functioning and provide a wide 43 panel of ecosystem services: (1) support, with the significant amount of ecological 44 niches (Dubois et al. 2002; Jones et al. 2018); (2) regulation, through the sediment 45 stabilization and trapping (Dubois et al. 2005); and (3) culture, by means of recreational 46 shore fisheries (Plicanti et al. 2016). As a biodiversity hotspot and a rare biological and 47 patrimonial heritage, BMSM worm reefs benefit from the European Habitats Directive

http://mc.manuscriptcentral.com/tres Email: IJRS-Administrator@Dundee.ac.uk 
1 (Council Directive 92/43/EEC) focusing on the protection and "Conservation of Natural 2 Habitats" ("biogenic reefs of open seas and tidal areas", habitat type 1170). However, 3 Sainte-Anne reefs are threatened by local anthropogenic activities, such as seaward 4 intensive Pacific oyster (Magallana gigas) and mussel (Mytilus edulis) aquaculture, which increases organic and mineral (silt) seston concentration (Dubois et al. 2009), interspecific competition for food and space by oyster and mussel that colonize reef surface (Dubois et al. 2006), and shell fishing on reefs, that cause fragmentation by trampling and destructive fishing techniques (Plicanti et al. 2016). Pressure synergy has led to a strong reduction in reef health state between 1970 to 2007 , as revealed by diachronic estimates of a spatial "Reef Health Status Index" (Desroy et al. 2011).

The previous index is the combination of a set of biological (e.g. epibiont covers) and physical (e.g. fragmentation) features of the reef, aimed at quantifying the health (Desroy et al. 2011). A consortium of European coastal scientists, devoted to honeycomb worm reef conservation, indicate that this index is "a complex timeconsuming assessment of the condition of reefs only, that is not widely applicable" (website: honeycombworms.org). Moreover, they advocate that "the usefulness of ... a generic health index for $S$. alveolata reefs ... should not involve laboratory experimentation, complex measurements or time-consuming processing". Remote sensing techniques hold great promises to address this issue given their nonintrusiveness, ease to use and cost-effectiveness per surface unit (large extent at high resolution). Spaceborne multispectral and hyperspectral, as well as airborne light detection and ranging (LiDAR) and unmanned vehicle (UAV) imageries were successfully utilized for mapping coral reefs (Collin, Hench and Planes 2012; Kutser, Miller and Jupp 2006; Collin et al. 2018a; and Casella et al. 2016), but are still lacking for other reefs, such as annelids. Whereas worm reefs were remotely-sensed by sidescan sound detection and ranging (SoNAR, Moore et al. 2008; Degraer et al. 2008; Raineault, Trembanis and Miller 2012; Pearce et al. 2014) and aerial visible (red-greenblue, RGB) photograph interpretation (Brown and Miller 2011; Godet et al. 2011), only two studies used optical data (including infrared, IR). Satellite multispectral imagery (SPOT-4) enabled S. alveolata reefs to be mapped at $20 \mathrm{~m}$ pixel size (Marchand and Cazoulat 2003), and airborne combination of RGB photo-interpretation and IR LiDAR elevation data at $2 \mathrm{~m}$ pixel size were used to delineate $S$. alveolata reefs' extent and estimate their volume (Noernberg et al. 2010). However, the application of both studies into a generic health index is challenging insofar as their spatial resolution is too coarse to account for ecophysiology and reef-building activity. More recent high to very high resolution (VHR) spaceborne optical data are not yet available over emerged reefs (lying between 2 and $4 \mathrm{~m}$ elevation above the national tidal datum epoch), since they are immersed most of the time. The Ortholittorale V2 product, collected by the French Ministry for Ecology, Sustainable Development and Energy (MEDDE) at low tide, remains, to date, the only VHR optical imagery $(0.5 \mathrm{~m}$ pixel size $)$ available over the honeycomb worm reefs.

Here we created a method for mapping emerging biogenic reefs at VHR using airborne optical image and selected field data, by focusing on $S$. alveolata relative abundance (Saa). The passive, optical imagery (ranging from infrared to blue wavebands at $0.5 \mathrm{~m}$ pixel size), acquired from a small aircraft, constitutes the remotelysensed predictors, and an array of RGB photoquadrats $\left(0.5 \times 0.5 \mathrm{~m}^{2}\right)$ is processed to retrieve the Saa relative abundance, as the ground-truth response. Following comparisons of model performance, the ANN is implemented to provide a non-linear 
regression between both datasets. Our study takes place over Sainte-Anne reefs (Fig. 1a, $21 b$ and $1 c$ ), in the heart of BMSM, provided with a maximum tidal range of $14 \mathrm{~m}$. 3 Despite the interest on a single parameter, the Saa open tubes (Fig. 1d) is deemed as a 4 good proxy for the reef state, given the threats related to silt sedimentation, oyster and 5 mussel colonization, as well as man-made physical degradation. This novel approach 6 has a great potential to contribute to the mapping of worldwide emerging biogenic reefs, 7 aiming at some health indices. Two methodological issues are raised: what are the best 8 spectral predictors? What is the optimized model complexity, featured by the number of 9 neurons? Once the Saa accurately mapped, we examine the spatial patterns of this reef state proxy. Findings are then discussed from the perspective of stakeholders tasked with management of the conservation of intertidal biogenic species adversely affected by anthropogenic activities.

\section{Materials and methods}

\subsection{Study site}

Sainte-Anne reefs, composed of three adjacent reefs, are situated on the central part $\left(48^{\circ} 38^{\prime} 50^{\prime \prime} \mathrm{N}, 1^{\circ} 40^{\prime} \mathrm{W}\right)$ of the megatidal (14 m tidal range) Bay of Mont-Saint-Michel (BMSM). Lying between 2 and $4 \mathrm{~m}$ elevation (Noernberg et al. 2010) over the French hydrographic zero (i.e., national tidal datum epoch), the Sainte-Anne reefs are spreading over $2.23 \mathrm{~km}^{2}$ with an estimated volume of $96301 \mathrm{~m}^{3}$ (Noernberg et al. 2010). They face massive mussel farming, structured by rows of wooden piles, lying from 0 to $2 \mathrm{~m}$ elevation. As the largest intertidal bioconstruction in Europe, the Sainte-Anne reef dynamics can occur in three main morphological shapes (Dubois et al. 2002): isolated hummocks (ball-shaped structures), coalescent hummocks forming mounds, then platforms. These three stages are modulated by transitional and degraded intermediate stages. Each stage is associated with various sessile species assemblages (M. gigas, $M$. edulis, $C$. fornicata, green, brown and red macroalgae) and specific demographic patterns of $S$. alveolata. Sediment grain-size is essentially composed of gravel, sand and silt classes.

\subsection{Ground-truth $\mathrm{S}$. alveolata abundance (Saa) response}

Fieldwork was carried out on June 26, 2017 using two quadrats $\left(0.5 \times 0.5 \mathrm{~m}^{2}\right.$, Fig. $\left.2 a\right)$, framing RGB photographs, collected with two cameras (Olympus Stylus TG). A series of 303 photoquadrats, geolocated in the WGS84 datum with GNSS devices (Garmin eTrex $\left.{ }^{\circledR}\right)$, were taken, by foot, at spring low tide between UTC $13 \mathrm{~h}$ and $15 \mathrm{~h}(14 \mathrm{~h} 51: 1.3$ $\mathrm{m}$ water level elevation). Photoquadrats were sampled to encompass the greatest reef health variability revealed by the most recent mapping work (Rollet et al. 2015). Each photoquadrat was standardized by the following procedure: (1) correction for the geometry acquisition through a distortion method carried out with Photoshop ${ }^{\circledR}$ (Fig. $2 b$ ), (2) cropping the image within the frame (Fig. $2 c$ ), and superimposition of a $5 \times 5$ grid to analyse independently the 25 image cells (Fig. $2 d$ ).

The standardized photoquadrat enabled the relative abundance (relative area
42 covered by various classes in the $0.25 \mathrm{~m}^{2}$ plot) of two polychaetes ( $S$. alveolata and

43 Lanice conchilega), three bivalves (M. gigas, M. edulis and C. fornicata), fleshy 
macroalgae, dead bivalves, gravel, sand, slit and water classes to be quantified. The spatially-dominant class in each of the 25 cells "wins" the cell, and then the relative abundance was computed as the sum of the 25 cells divided by 25 . We only exploited the relative abundance of $S$. alveolata (Saa), by means of open tubes' recognition. For the sake of visual interpretation, eight relative abundances of Saa were visually represented by photoquadrats along with their ecological assemblage and reef morphology stage, according to Dubois et al. 2002 (Table 1).

Figure 2

Table 1

\subsection{Optical imagery predictors}

The airborne optical survey was conducted on September 10, 2014 (UTC 14h00; $0.36 \mathrm{~m}$ water level elevation) using two full frame charge coupled device (CCD) multispectral cameras: one (UltraCam-Xp, $33 \mathrm{~mm}$ focal length) acquiring red, green, and blue wavebands (RGB, Fig. 3a), and the other one (UltraCam-XpWA, $23 \mathrm{~mm}$ focal length), collecting infrared, red and green wavebands (IRRG, Fig. $3 b$ ). Spectral responses of the four optical wavebands are summarized in Table 2. Analog image data are recorded at 12 bits, converted to digital numbers at 14 bits, stored without compression at 16 bits, and finally delivered at 8 bits (USGS 2010). The freely-available Ortholittorale V2 product (see hyperlink in Acknowledgments section) has covered all French coastlines, in 2014, with a rigorous acquisition protocol, but does not provide spectral specificities of both sensors. The six wavebands, captured with 8-bit radiometric resolution, were orthorectified at $0.5 \mathrm{~m}$ spatial resolution in the RGF93 datum (GRS80 spheroid) projected with Lambert93 (conformal conic), the referential French system. Spectral wavebands were highlighted using four spectral signatures associated with four primary features (water, sand, reef and algae), easily discriminated though image-based inspection (Fig. 3c).

Insofar as the objective of this study is to target submeter Saa, a thorough registration of coarsely geolocated photoquadrats onto spectral layers was carried out. First, the geographic coordinates of ground-truth were converted into the RGF93 datum, then projected in Lambert93. Second, the converted geolocations were refined by adding the horizontal offset derived from the GNSS measurements and imagery geolocations of eight isolated hummocks, clearly distinctive over imagery. Third, the submeter registration was achieved by translating, where necessary, the refined geolocations onto the correct features using an ultra high resolution UAV-stemmed imagery $\left(0.08 \times 0.08 \mathrm{~m}^{2}\right.$, Collin et al. $\left.2018 \mathrm{~b}\right)$.

\section{Figure 3}

\subsection{Artificial neural network modelling}

Preliminary comparisons of three main regression learners (ordinary least squares, OLS; generalized linear model, GLM; and ANN) were carried out, resulting in the ANN selection (Table 3), corroborating another comparison study (Collin, Etienne, and Feunteun 2017). The ANN was selected to develop a robust model to link the discrete Saa response with continuous multispectral predictors.

Based on non-linear modelling, $h$, the ANN minimizes least squares using a fully-connected single-layer perceptron feed-forward workflow to predict the Saa response, $h(X)$, from a, activated (hyperbolic tangent function, $k$ ) sum of the $i$ (ranging from 1 to 7) appropriately weighted, $w_{\mathrm{i}}$, neurons, $n_{\mathrm{i}}$, resulting themselves from an 
appropriate weighting of the multispectral predictors, $X$ (Heermann and Khazenie 2 1992):

3

4

$$
h(X)=k\left(\sum_{i} w_{i} n_{i}(X)\right)
$$

Constrained by a single hidden layer, ANN models were developed to test how relevant are the number of neurons, jointly with the implemented spectral combination.

\subsection{Accuracy assessment}

Ground-truth dataset was firstly sorted according to the Saa values, and secondly stratified into 202 calibration and 101 validation subsets (Holdout method) in order to test the acceptability of the modelling. The calibration dataset was subject to 1000 computation runs to reach convergent results and therefore avoid stochastic influences, such as the weight initialization. The matching between observed and predicted Saa, based on the validation dataset, was quantified using the coefficient of determination $\left(R^{2}\right)$ and the root mean square error (RMSE) of the corresponding linear regression, as well as the corresponding Pearson product-moment correlation coefficient $(r)$.

\section{Results}

\subsection{Spectral combination and model complexity}

The 101 validation values of Saa were negatively correlated with all spectral wavebands $\left(r_{\text {Red }}=-0.70, r_{\text {Green }}=-0.76, r_{\text {Blue }}=-0.74, r_{\text {InfraRed }}=-0.58, r_{\text {Red }}=-0.68, r_{\text {Green }}=-0.74\right)$. The influence of the spectral combinations along with the ANN complexity, by interest in the number of neurons in the hidden layer, was tested using the performance metrics of both high $R^{2}$ and low RMSE (Fig. 4a). Overall the agreement between observed and predicted Saa was satisfactory, ranging from a $R^{2}$ of 0.67 to 0.72 (Fig $4 a$ ). The best spectral combination was averagely the IRRG $\left(R^{2}=0.71\right)$, followed by RGB+IRRG $\left(R^{2}\right.$ $=0.70)$, and finally $\operatorname{RGB}\left(R^{2}=0.68\right)$ (Fig. 4A). The ANN complexity was optimized with six neurons in the intermediate hidden layer $\left(R^{2}=0.71\right)$ (Fig. $\left.4 a\right)$. The best ANN model was built using the IRRG spectral combination with the six neurons $\left(R^{2}=0.72\right.$, RMSE $=0.08$, and $r=0.85$, Fig. $4 b$ ). The architecture of the selected ANN model was represented in order to make explicit the doubling number of neurons, compared to the number of input layers (Fig. 5).

\section{Figure 4}

Figure 5

\subsection{Spatially-explicit modelling of S. alveolata abundance (Saa)}

The six hyperbolic tangent formulas were applied to the three input spectral bands (IRRG) in order to build six hidden neuronal bands, in turn, implemented into the output linear formula, leading to VHR digital Saa model (Fig. 6, $6547 \times 6566$ pixels with $0.5 \mathrm{~m}$ pixel size).

\section{Figure 6}




\section{Discussion}

\subsection{Spectral detection of S. alveolata abundance (Saa) and socio-ecology}

The use of the airborne optical imagery (available over all French metropolitan and most overseas coastal fringes, $\approx 18000 \mathrm{~km}$, at low spring tide) has enabled the accurate mapping of the most extended biogenic reef in Europe (i.e., the Sainte-Anne reefs). Enriching the RGB first product of Ortholittorale (2000) by IRRG, the second version (2014) has leveraged the informational IR waveband. In a broadened context of coastal biogenic reef mapping, some spectral and spatial lessons can be drawn. The interpretation of the visible aerial photography, likely to be constrained by the analyst experience (Brown and Miller 2011, Godet et al. 2011), can be augmented by machine learning procedures (our ANN and cellular automata modelling from Marchand and Cazoulat 2003). Contrary to submerged coral reefs, the emerging biogenic reefs can be better mapped using the IR, strongly absorbed by water and reflected by plant pigment. Enriching the passive RGB dataset, IR-derived LiDAR topography can measure the volume of emerging reefs (Noernberg et al. 2010), even if the LiDAR IR intensity has not been used yet, contrary to salt marshes (Collin, Long and Archambault 2010). The integration of the active LiDAR IR and G backscatters with the passive RGB imagery is strongly advocated to refine the emerging reefs, and will be soon possible given the current airborne topobathymetric LiDAR mapping of French coastal fringe (Litto3D $\mathbb{}$ website: diffusion.shom.fr/pro/risques/altimetrie-littorale.html). The $0.5 \mathrm{~m}$ resolution encountered in our study outperformed terebellidae and sabellariidae works $(100 \mathrm{~m}$ in Godet et al. 2011, $75 \mathrm{~m}$ in Rollet et al. 2015 and Desroy et al. 2011, $20 \mathrm{~m}$ in Marchand and Cazoulat 2003, and $2 \mathrm{~m}$ in Noernberg et al. 2010).

Despite the coarse spectral bandwidths, the signature of the reef indicates a low reflection in the visible spectrum, with a slight increase from green (G) to infrared (IR) (Fig. 3c). Increasingly negative correlations between Saa and IR, red (R), blue (B) and $\mathrm{G}$ show that the reef health proxy might be described by a differential variation occurring between IR and G. Likewise the Normalized Difference Water Index ratioed the G and IR Landsat TM wavebands (McFeeters 1996). Further spectral investigations, using a portable hyperspectral sensor, are needed to conclude about the key role played by water (moisture) in the reef health mapping. The precise spectral signature of Saa and neighbouring features will also enable a VHR spaceborne proxy to be developed for worm reefs, as successfully done for coral reefs using WorldView-2 imagery (Collin and Planes 2012; Collin, Hench, and Planes 2012). The strong negative correlation between reef health with $\mathrm{G}$ might also match the low presence of green macroalgae (e.g. Ulva spp.), as highlighted by a long-term survey of the Sainte-Anne reefs health status (Desroy et al. 2011). In this respect, BMSM combines high levels of nutrients, as the junction of landward agricultural runoff and seaward intensive mussel aquaculture, thus favouring the opportunistic seaweed colonization at the expense of $S$. alveolata open tubes. Such a calibrated ANN approach should draw attention to focus on the mapping of green macroalgae. Those fleshy macroalgae have been evidenced to affect recruitment patterns (Dubois et al. 2006) but also to potentially contribute to the suspension-feeders' diets, including S. alveolata (Lefebvre et al. 2009; Dubois and Colombo 2014). While eutrophication impacts on S. alveolata reefs have not been investigated, recent studies emphasised adverse effects on coral reefs (Prouty et al. 2017). In a context of ocean acidification, influence on lower $\mathrm{pH}$ on this carbonate-rich reef (made of $60-80 \%$ of calcium carbonate grains, Caline et al. 1992) or on biogenic cement polymerisation (Fournier et al., 2010) consist of relevant research avenues. 


1

Other competitors for space have been targeted, such as farmed M. gigas (Desroy et al. 2011), M. edulis but also naturally-present M. galloprovincialis (Jones et al. 2018), whose spatial distribution could importantly explain reef patterns. Based on the occurrence derived from our ground-truth, we greatly recommend taking the invasive gastropod $C$. fornicata mapping into account, due to its trophic competition as a massive population of suspension-feeders.

\subsection{A VHR method to monitor S. alveolata abundance (Saa) patterns}

Our spatial modelling has enabled the mapping of Saa at VHR using a reliable method. Fieldworks conducted in April 2015 by Rollet et al. (2015), required 15 persons during two days to survey 307 stations using a regular $75 \mathrm{~m} \times 75 \mathrm{~m}$ grid mapping (as described in Desroy et al. 2011 for 2001 and 2007 similar survey). Even though such in situ studies have led a comprehensive dataset (sediment, epifauna and health status), the spatial scale at stake conspicuously mismatched the fine-scale patterns of $S$. alveolata ecology.

Our outcomes, based on airborne imagery and two persons during one day for 303 calibration/validation stations, allow reef ecomorphology to be sharply examined, gaining insights into reef responses to exogeneous drivers (Fig. 7). The digital Saa model distinctly elucidates a strong polarization of Saa values: highest Saa at the front of reefs, firstly exposed to sea hydrodynamics and potentially higher coarse sediments and bioclast resuspension (hence increased tube-building activity), contrary to the back of reefs with lowest Saa, lying on more sheltered and muddier environments (BonnotCourtois et al. 2008). The back-reef is subject to finer grained resources, which hamper filtration activity as tentacular filaments of $S$. alveolata are clogged and gut contents are more rapidly filled by poor-quality suspended food sources due to an increase in inorganic content (Dubois et al. 2005). Moreover, apparently unhealthy state of the back-reef might be due to the higher occurrences of oysters, hence leading to higher trampling and destructive shell fishing techniques (Plicanti et al. 2016). In addition to the characterization of the reef polarization perpendicular to the shoreline, the VHR Saa mapping feature five separated reefs composing Sainte-Anne (unlike the three main parts identified in Desroy et al. (2011): a central front barrier reef with a vigorous front core and northern small seaward elongations, a northern crescent reef with developed seaward elongations, a southern crescent reef, two massive intermediate (between sea and land) coalescent reefs. Further examinations of landscape connectivity (using dedicated software, such as Graphab) may facilitate modelling of ecological networks and ultimately help stakeholders to include biodiversity conservation into coastal spatial planning.

\section{Figure 7}

\section{Conclusion}

This novel research shows that airborne optical imagery, ranging from green to infrared, brings enough information to robustly map emerging biogenic reefs at VHR. The original findings derived from the largest bioconstruction in Europe (honeycomb worm reefs) can be summarized as follows:

(1) S. alveolata relative abundance (Saa) of emerging reefs can be fully surveyed by airborne RGB and/or IRRG cameras at the colony-scale $(0.5 \mathrm{~m})$ during low spring tide

(2) IRRG are better predictors of Saa than $\operatorname{RGB}\left(R^{2}=0.71\right.$ and 0.68 , respectively) 
(3) Adding RGB to IRRG reduce the prediction performance of Saa $\left(R^{2}=0.70\right)$

(4) ANN, as a robust non-linear model, is optimized with a hidden layer provided with six neurons in order to predict Saa $\left(R^{2}=0.71\right)$

(5) The best prediction of Saa was reached with the IRRG spectral combination and ANN model structured with six neurons $\left(R^{2}=0.72, \mathrm{RMSE}=0.08\right.$, and $\left.r=0.85\right)$

\section{Acknowledgments}

Authors gratefully thank French Minister for Ecology, Sustainable Development and Energy for the airborne multispectral acquisition and dissemination related to Ortholittorale V2 product (http://cartelie.application.developpementdurable.gouv.fr/cartelie/voir.do?carte=telecharg_ol_v2_193\&service=CEREMA). Hélène Gloria and Dorothée James are also greatly acknowledged for their fieldwork involvement.

\section{References}

Andres, M.S., and R.P. Reid. 2006. "Growth morphologies of modern marine stromatolites: a case study from Highborne Cay, Bahamas". Sedimentary Geology 185(3-4): 319-328.

Bonnot-Courtois C., P. Bassoulet, B. Tessier, F. Cayocca, P. Le Hir, and A. Baltzer. 2008. "Remaniements sédimentaires superficiels sur l'estran occidental de la baie du Mont-SaintMichel." European Journal of Environmental and Civil Engineering 12: 51-65.

Bonnot-Courtois, C., B. Caline, A. L'Homer, and M. Le Vot, M. 2002. "The Bay of Mont-SaintMichel and the Rance Estuary, recent development and evolution of depositional environments". Mémoire 26, CNRS, EPHE, TotalFinaElf, Pau, 256 p.

Brown, J.R., and D.C. Miller. 2011. "Persistence and distribution of temperate intertidal worm reefs in Delaware Bay: a comparison of biological and physical factors". Estuaries and coasts 34(3): 583-596.

Caline, B., Y. Gruet, C. Legendre, J. Le Rhun, A. L'Homer, R. Mathieu, and R. Zbinden. 1992. "The Sabellariid reefs in the Bay of Mont Saint-Michel, France. Ecology, Geomorphology, Sedimentology and Geologic Implications". Edited and translated by David W. Kirtley, Florida Oceanographic Society, Contributions to Marine Science 1, Stuart, Florida, 156 p.

Casella, E., A. Collin, D. Harris, S. Ferse, S. Bejarano, V. Parravicini, V., J.L. Hench, and A. Rovere. 2017. "Mapping coral reefs using consumer-grade drones and structure from motion photogrammetry techniques". Coral Reefs 36(1): 269-275.

Collin, A., and S. Planes. 2012. "Enhancing coral health detection using spectral diversity indices from worldview-2 imagery and machine learners." Remote Sensing 4(10): 32443264.

Collin, A., B. Long, B., and P. Archambault. 2010. "Salt-marsh characterization, zonation assessment and mapping through a dual-wavelength LiDAR". Remote Sensing of Environment 114(3): 520-530.

Collin, A., C. Ramambason, Y. Pastol, E. Casella, A. Rovere, L. Thiault, B. Espiau, G. Siu, F. Lerouvreur, N. Nakamura, J. Hench, R. Schmitt, S. Holbrook, M. Troyer, and N. Davies. 2018a. "Very High Resolution mapping of coral reef state using airborne bathymetric LiDAR surface-intensity predictors, visible drone response, and neural network". International Journal Remote Sensing re-submitted.

Collin, A., J.L. Hench, and S. Planes. 2012. "A novel spaceborne proxy for mapping coral cover." In Proceedings of the $12^{\text {th }}$ International Coral Reef Symposium, Cairns, 1-5.

Collin, A., S. Dubois, D. James, C. Ramambason, H. Gloria, E. Feunteun, and S. Etienne. 2018b. "Complexité structurale des récifs biogéniques d'hermelles par drone”. In merIGéo, Aix-en-Provence, 23-26.

Collin, A., S. Etienne, and E. Feunteun. 2017. "VHR coastal bathymetry using WorldView-3: colour versus learner." Remote Sensing Letters 8(11): 1072-1081.

Degraer, S., G. Moerkerke, M. Rabaut, G. Van Hoey, I. Du Four, M. Vincx,... and V. Van Lancker. 2008. Very-high resolution side-scan sonar mapping of biogenic reefs of the tubeworm Lanice conchilega. Remote Sensing of Environment 112(8): 3323-3328. 
Desroy, N., S. Dubois, J. Fournier, L. Ricquiers, P. Le Mao, P., L. Guérin, L., ... and A. Legendre. 2011. "The conservation status of Sabellaria alveolata (L.)(Polychaeta: Sabellariidae) reefs in the Bay of Mont-Saint-Michel". Aquatic Conservation: Marine and Freshwater Ecosystems 21(5): 462-471.

Donnarumma, L., R. Sandulli, L. Appolloni, F. Di Stefano, and G.F. Russo. 2017. "Morphostructural and ecological features of a shallow vermetid bioconstruction in the Tyrrhenian Sea (Mediterranean Sea, Italy)". Journal of Sea Research.

Dubois S.F., and F. Colombo. 2014. How picky can you be? Temporal variations in trophic niches of co-occurring suspension-feeding species. Food Webs 1: 1-9.

Dubois, S., C. Retière, and F. Olivier. 2002. "Biodiversity associated with Sabellaria alveolata (Polychaeta: Sabellariidae) reefs: effects of human disturbances". Journal of the Marine Biological Association of the United Kingdom 82(5): 817-826.

Dubois, S., J.A. Commito, F. Olivier, and C. Retière, C. 2006. "Effects of epibionts on Sabellaria alveolata (L.) biogenic reefs and their associated fauna in the Bay of Mont SaintMichel". Estuarine, Coastal and Shelf Science 68(3): 635-646.

Dubois, S., L. Barillé, and B. Cognie, B. 2009. "Feeding response of the polychaete Sabellaria alveolata (Sabellariidae) to changes in seston concentration". Journal of Experimental Marine Biology and Ecology 376(2): 94-101.

Dubois, S., L. Barillé, B. Cognie, and P.G. Beninger. 2005. "Particle capture and processing mechanisms in Sabellaria alveolata (Polychaeta: Sabellariidae)". Marine Ecology Progress Series 301: 159-171.

Fournier, J. Etienne, S., and J.B. Le Cam. 2010. "Inter- and intraspecific variability in the chemical composition of the mineral phase of cements from several tube-building polychaetes". Geobios 43: 191-200.

Gherardi, D.F.M., and D.W.J. Bosence. 2001. "Composition and community structure of the coralline algal reefs from Atol das Rocas, South Atlantic, Brazil”. Coral reefs 19(3): 205219.

Godet, L., J. Fournier, M. Jaffré, and N. Desroy. 2011. "Influence of stability and fragmentation of a worm-reef on benthic macrofauna". Estuarine, Coastal and Shelf Science 92(3): 472479.

Heermann, P. D., and N. Khazenie. 1992. "Classification of multispectral remote sensing data using a back-propagation neural network". IEEE Transactions on Geoscience and Remote Sensing 30(1): 81-88.

Jones A.G., S.F. Dubois, N. Desroy, and J. Fournier. 2018. "Interplay between abiotic factors and species assemblages mediated by the ecosystem engineer Sabellaria alveolata (Annelida: Polychaeta)". Estuarine Coastal and Shelf Science 200: 1-18.

Kutser, T., I. Miller, I., and D.L. Jupp. 2006. "Mapping coral reef benthic substrates using hyperspectral space-borne images and spectral libraries". Estuarine, Coastal and Shelf Science 70(3): 449-460.

Lefebvre S., J.C. Marin-Leal, S. Dubois, F. Orvain, J.L. Blin, M.P. Bataille, A. Ourry, and R. Galois. 2009. Seasonal dynamics of trophic relationships among co-occurring suspensionfeeders in two shellfish-culture dominated ecosystems. Estuarine Coastal and Shelf Science 82: $415-425$.

Marchand, Y., and R. Cazoulat. 2003. "Biological reef survey using spot satellite data classification by cellular automata method - bay of Mont Saint-Michel". Computers and Geosciences 29:413-421.

McFeeters, S.K. 1996. "The use of normalized difference water index (NDWI) in the delineation of open water features". International Journal of Remote Sensing 17: 14251432 .

Moore, C.G., C. Richard Bates, J.M. Mair, G.R. Saunders, D.B. Harries, and A.R. Lyndon. 2009. "Mapping serpulid worm reefs (Polychaeta: Serpulidae) for conservation management". Aquatic Conservation: Marine and Freshwater Ecosystems 19(2): 226-236.

Mumby, P.J., W. Skirving, A.E. Strong, J.T. Hardy, E.F. LeDrew, E.J. Hochberg, E. J., ... and L.T. David. 2004. "Remote sensing of coral reefs and their physical environment". Marine pollution bulletin 48(3-4): 219-228. 
Naylor, L.A., and H.A. Viles. 2000. "A temperate reef builder: an evaluation of the growth, morphology and composition of Sabellaria alveolata (L.) colonies on carbonate platforms in South Wales". Geological Society, London, Special Publications 178(1): 9-19.

Noernberg, M. A., J. Fournier, S. Dubois, and J. Populus. 2010. "Using airborne laser altimetry to estimate Sabellaria alveolata (Polychaeta: Sabellariidae) reefs volume in tidal flat environments." Estuarine, coastal and shelf science 90(2): 93-102.

Pearce, B., J.M. Fariñas-Franco, C. Wilson, J. Pitts, and P.J. Somerfield. 2014. "Repeated mapping of reefs constructed by Sabellaria spinulosa Leuckart 1849 at an offshore wind farm site". Continental Shelf Research 83: 3-13.

Plicanti, A., R. Domínguez, S. Dubois, and I. Bertocci. 2016. "Human impacts on biogenic habitats: Effects of experimental trampling on Sabellaria alveolata (Linnaeus, 1767) reefs". Journal of Experimental Marine Biology and Ecology 478: 34-44.

Prouty, N.G., A. Cohen, K.K. Yates, C.D. Storlazzi, P.W. Swarzenski, and D. White. 2017. "Vulnerability of Coral Reefs to Bioerosion From Land-Based Sources of Pollution". Journal of Geophysical Research: Oceans.

Raineault, N.A., A.C. Trembanis, and D.C. Miller. 2012. "Mapping benthic habitats in Delaware Bay and the coastal Atlantic: acoustic techniques provide greater coverage and high resolution in complex, shallow-water environments". Estuaries and Coasts 35(2): 682699.

Rollet C., D. Mathérion, N. Desroy, and P. Le Mao. 2015. "Suivi de l'état de conservation des récifs d'hermelles (Sabellaria alveolata)". Rapport final, décembre 2015, Ifremer/ODE/LITTORAL/LER/BN-15-008, Projet Life 12 ENV/FR/316 - Expérimentation pour une gestion durable et concertée de la pêche à pied de loisir - LIFE+ Pêche à pied de loisir, $32 \mathrm{p}$. + annexes.

United States Geological Survey. 2010. "Digital aerial sensor certification report for the Microsoft Vexcel UltraCamD, UltraCamX, UltraCamXp, and UltraCamXp WA Models". Department of the Interior US Geological Survey, $19 \mathrm{p}$. 

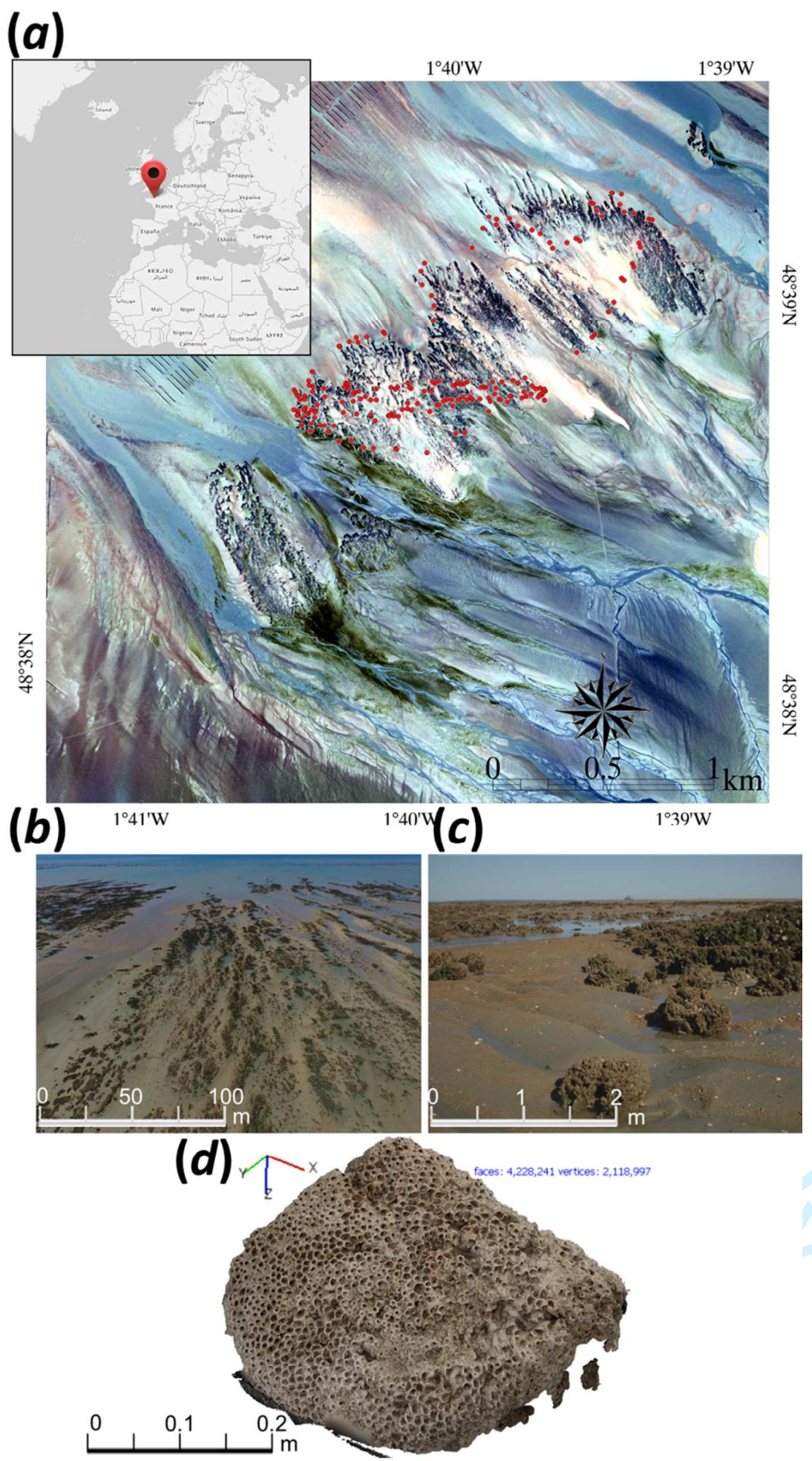

Figure 1. (a) Natural-coloured (red-blue-green) airborne imagery $(6547 \times 6566$ pixels with 0.5 $\mathrm{m}$ pixel size) collected on September 10, 2014, over the location of Sainte-Anne three honeycomb worm reefs (Sabellaria alveolata), within Bay of Mont-Saint-Michel (BrittanyNormandy, France). Red spots represent photoquadrat locations. (b) Natural-coloured airborne UAV oblique imagery over a portion of the Sainte-Anne reefs. (c) Natural-coloured handborne imagery inside the Sainte-Anne reefs. (d) 3D-model of a honeycomb worm hummock colony draped with natural-coloured imagery. 
1

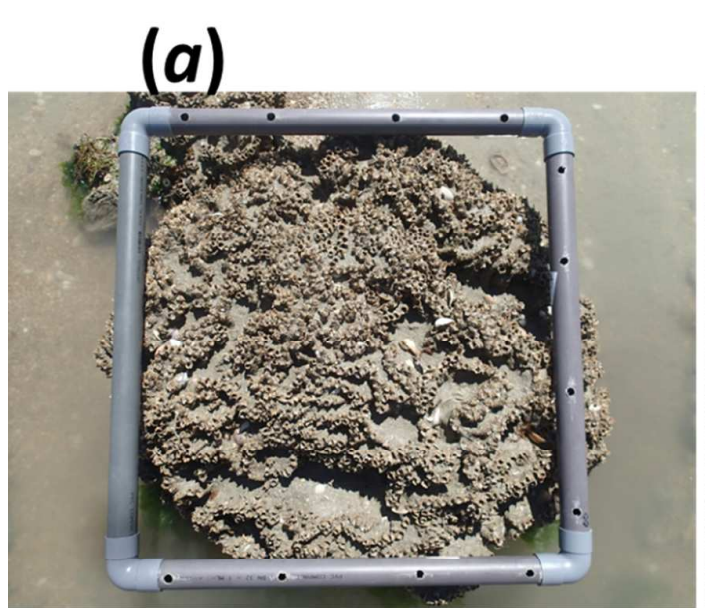

(c)

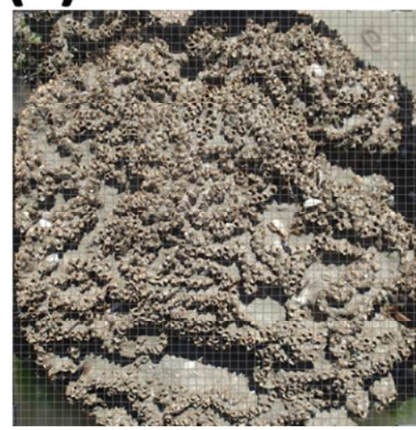

2

4

5

6

7

8

Figure 2. Standardization procedure applied to the $(a)$ original photoquadrat, $(b)$ to correct for the distortion, $(c)$ to crop at the frame scale $\left(0.5 \times 0.5 \mathrm{~m}^{2}\right)$, and $(d)$ to apply a $5 \times 5$ grid. 
(a)

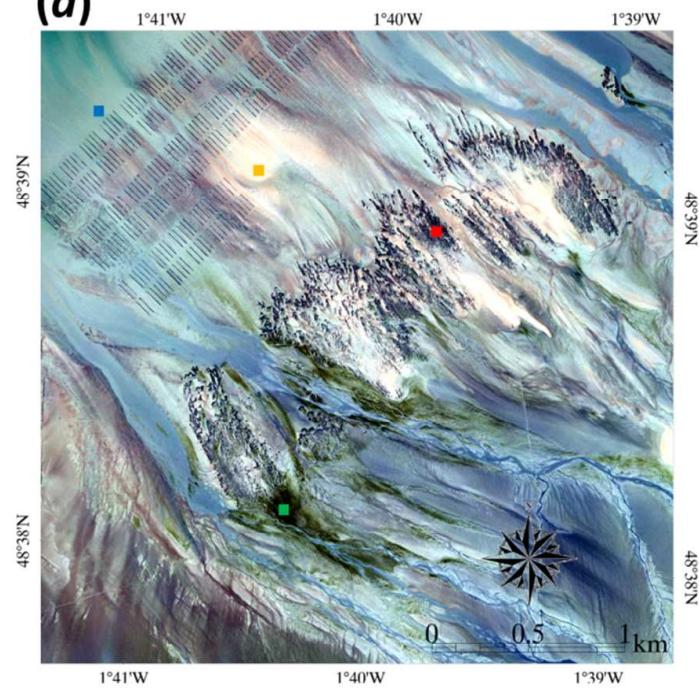

(b)

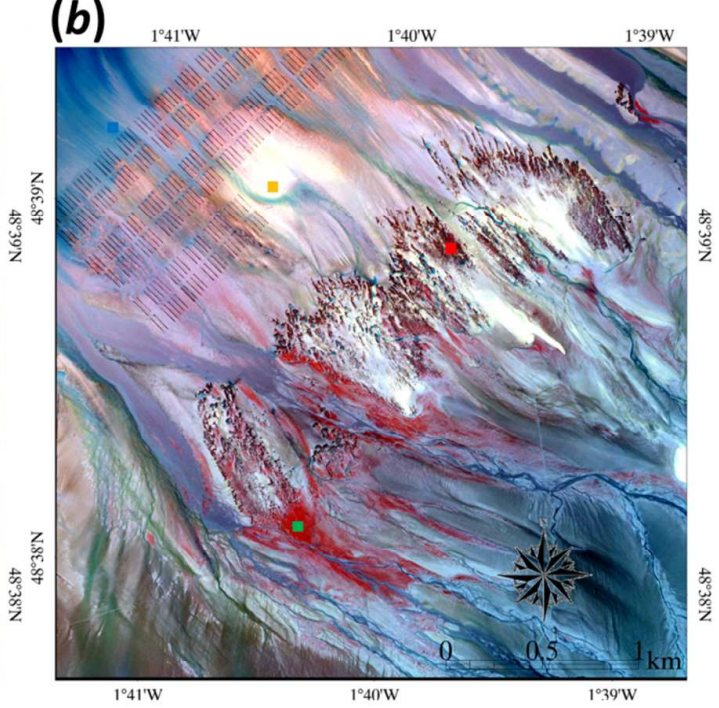

(c)

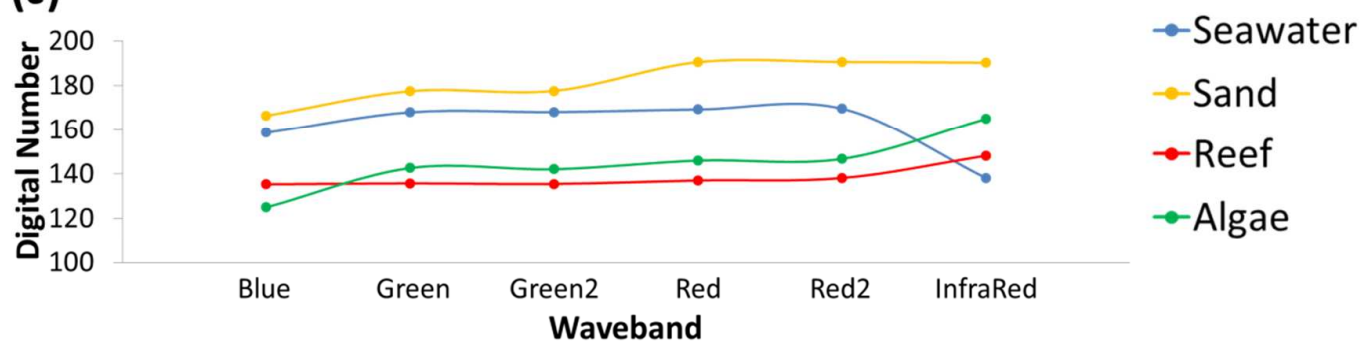

Figure 3. ( $a$ ) Natural-coloured (red-blue-green), and (b) infrared-coloured (infrared-red-green) airborne imageries $(6547 \times 6566$ pixels with $0.5 \mathrm{~m}$ pixel size $)$ collected on September 10, 2014, over the location of Sainte-Anne reefs. (c) Four rectangles were selected by visual inspection for determining spectral signatures based on Ortholittorale V2 of seawater (blue), sand (yellow), reef (red), and algae (green).

(a)

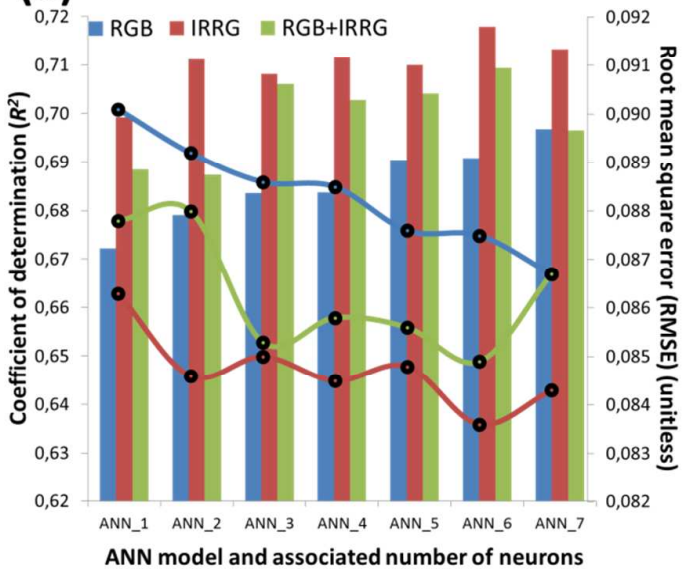

(b)

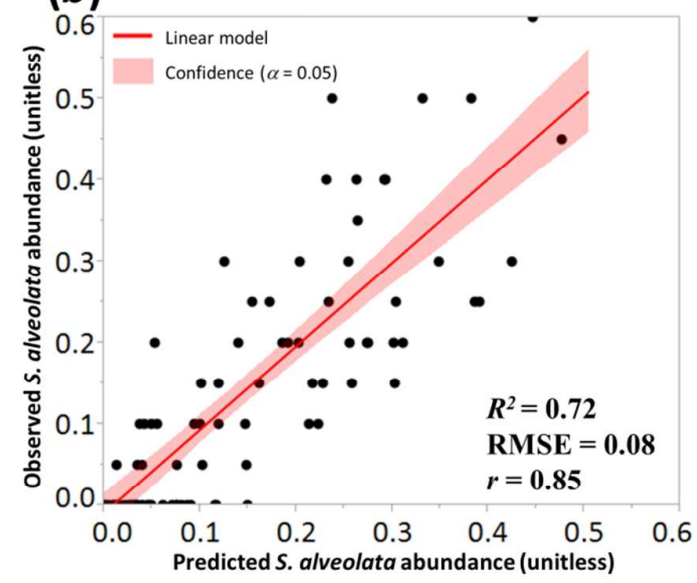

Figure 4. (a) Bar and line plot of the performance (coefficient of determination, $R^{2}$, and root mean square error, RMSE, respectively) of the 21 artificial neural network (ANN) models predicting the validation dataset of Sabellaria alveolata abundance $(N=101)$, as functions of spectral combination inputs and number of hidden neurons. (b) Scatterplot of the validation versus predicted $S$. alveolata abundance based on the best ANN model (IRRG as input layers and six neurons within hidden layer). 


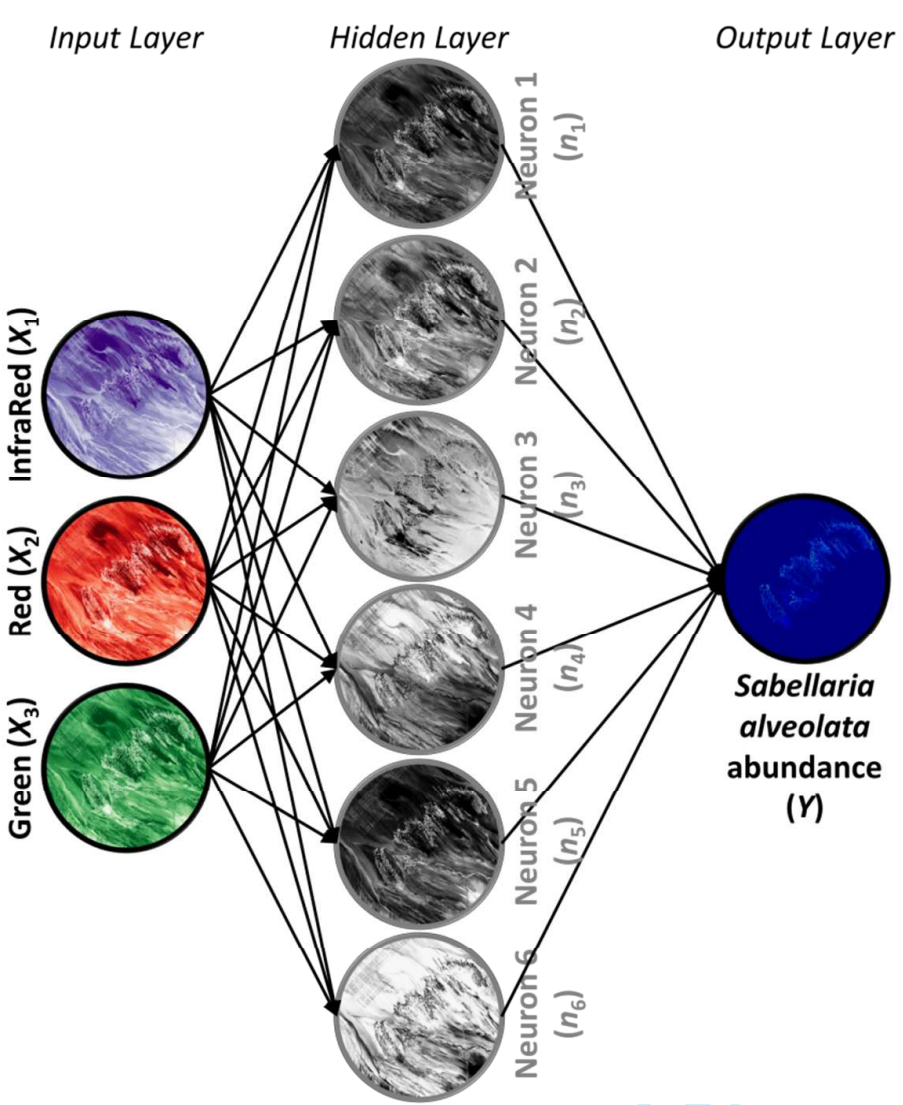

3 Figure 5. Conceptual flowchart of the artificial neural network modelling based on the infrared, 4 red and green input layers, the hidden layer provided with six neurons to be able to predict the 5 Sabellaria alveolata abundance. 
$1^{\circ} 41^{\prime} \mathrm{W}$

$1^{\circ} 40^{\prime} \mathrm{W}$

$1^{\circ} 39^{\prime} \mathrm{W}$

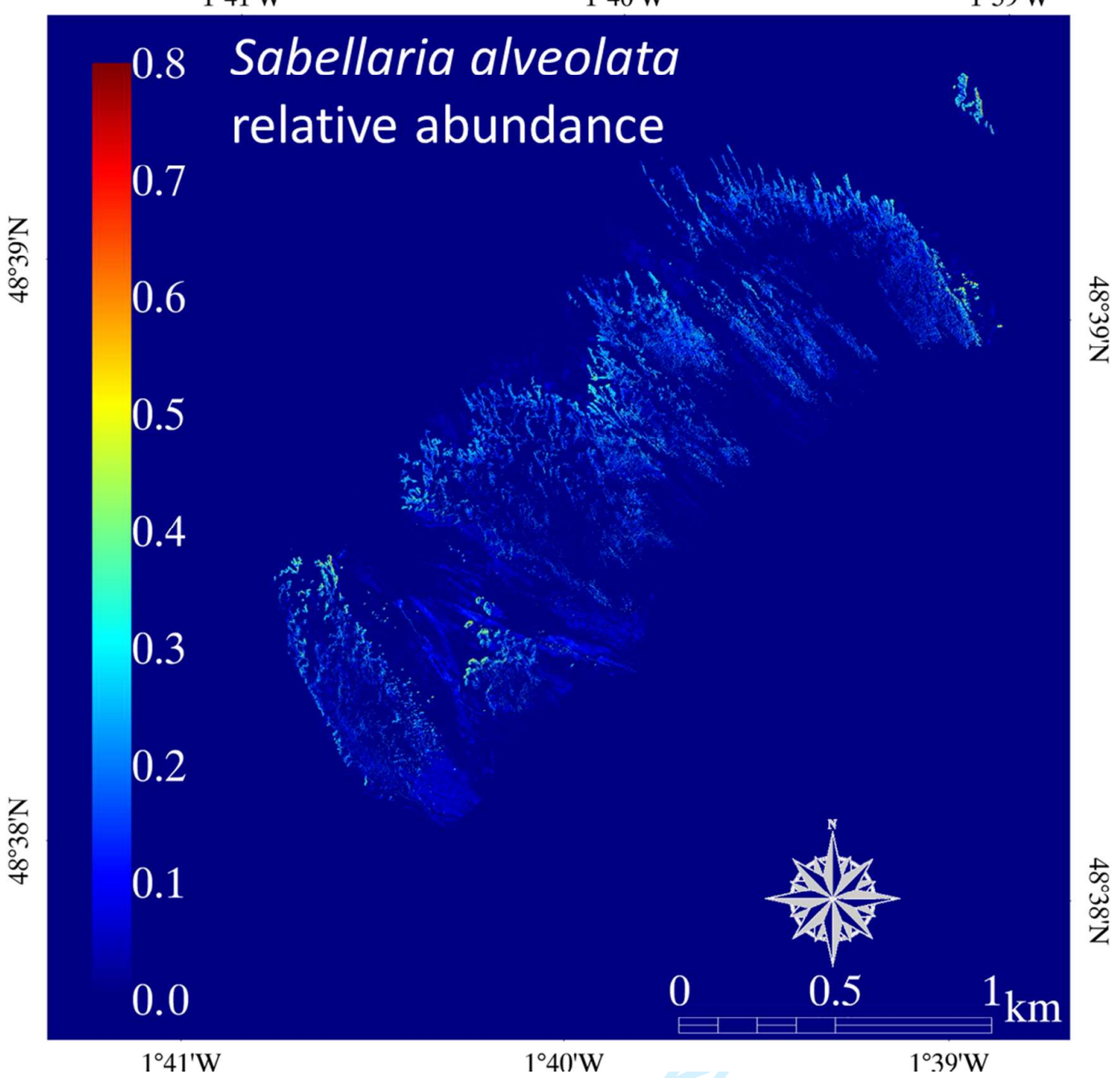

Figure 6. Digital Sabellaria alveolata abundance model derived from artificial neural network model with airborne infrared, red and green bands as input layers and six neurons within hidden layer $(6547 \times 6566$ pixels at $0.5 \mathrm{~m}$ pixel size $)$. 


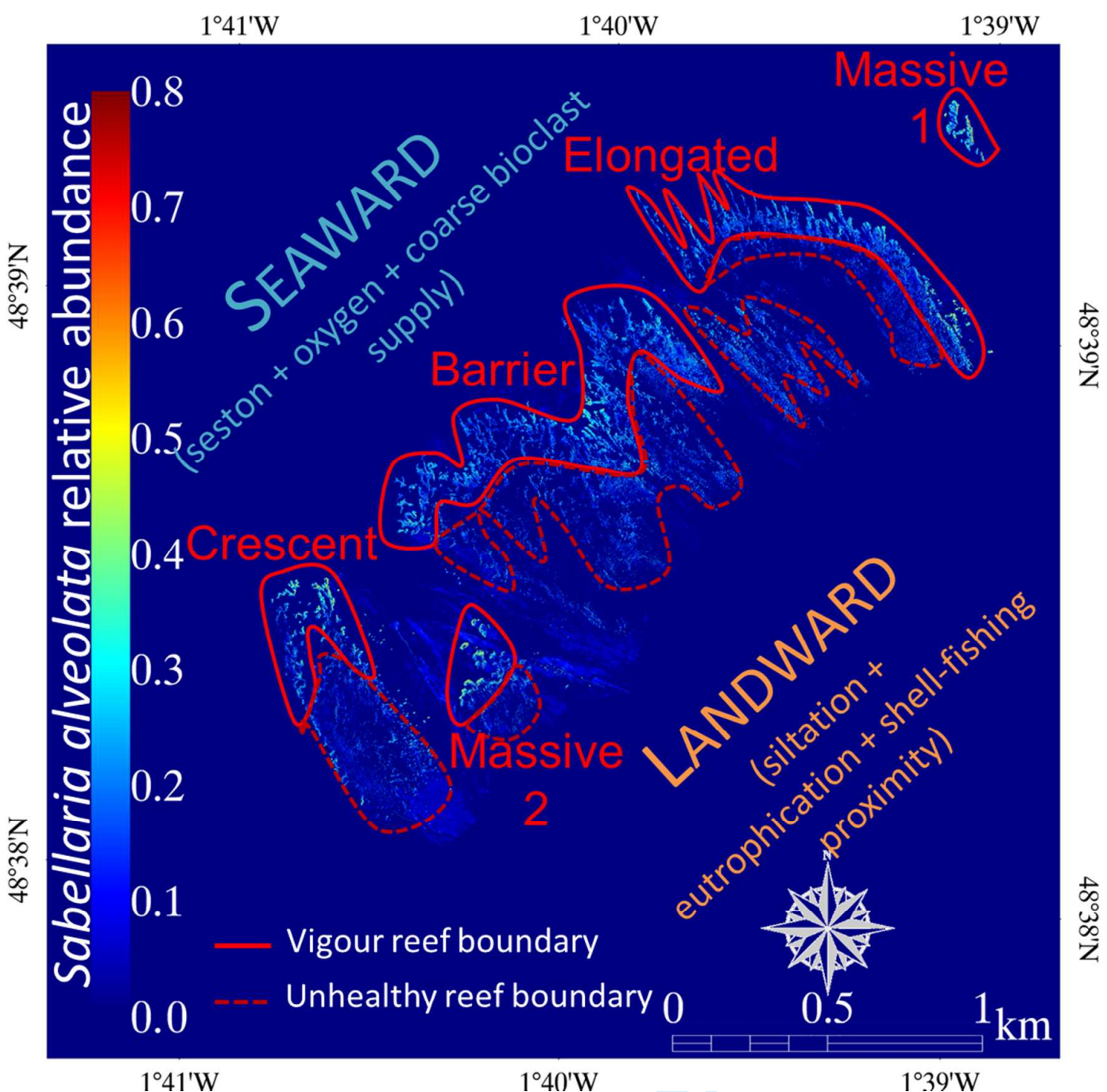

2 Figure 7. Synthetic conceptual diagram proposing explanation factors of polarized Sabellaria 3 alveolata abundance in Sainte-Anne reefs, based on the model derived from artificial neural 4 network model with airborne infrared, red and green bands as input layers and six neurons 5 within hidden layer $(6547 \times 6566$ pixels at $0.5 \mathrm{~m}$ pixel size $)$. 


\begin{tabular}{|c|c|c|c|c|}
\hline $\begin{array}{l}\text { Photoquadrat- } \\
\text { based class }\end{array}$ & Ecological assemblage & $\begin{array}{c}\text { Sabellaria } \\
\text { alveolata } \\
\text { relative } \\
\text { abundance }\end{array}$ & $\begin{array}{c}\text { Worm reef } \\
\text { morphology } \\
\text { stage (Dubois } \\
\text { et al. 2002) }\end{array}$ & Colour ramp \\
\hline & $\begin{array}{l}\text { Sand/silt with dead } \\
\text { bivalves (shells) }\end{array}$ & 0.0 & $\begin{array}{c}\text { No } S \text {. } \\
\text { alveolata } \\
\text { presence }\end{array}$ & \\
\hline & $\begin{array}{l}\text { M. gigas / M. edulis / } C \text {. } \\
\text { fornicata / fleshy } \\
\text { macroalgae / sand / silt / } \\
\text { S. alveolata }\end{array}$ & 0.1 & $\begin{array}{l}\text { Degraded } \\
\text { isolated } S \text {. } \\
\text { alveolata } \\
\text { hummock }\end{array}$ & \\
\hline & $\begin{array}{l}\text { S. alveolata / sand / silt } \\
\text { / M.gigas / M. edulis / } \\
\text { C. fornicata / fleshy } \\
\text { macroalgae }\end{array}$ & 0.2 & $\begin{array}{l}\text { Isolated } S \text {. } \\
\text { alveolata } \\
\text { hummock }\end{array}$ & \\
\hline & $\begin{array}{l}\text { S. alveolata / sand / silt } \\
\text { / shells }\end{array}$ & & $\begin{array}{l}\text { Isolated } S \text {. } \\
\text { alveolata } \\
\text { hummock }\end{array}$ & \\
\hline & $\begin{array}{l}\text { S. alveolata / sand / silt } \\
\text { / shells }\end{array}$ & 0.4 & $\begin{array}{c}\text { Isolated } S \text {. } \\
\text { alveolata } \\
\text { hummock }\end{array}$ & \\
\hline & S. alveolata / silt / shells & 0.5 & $\begin{array}{l}\text { Coalescent } S \text {. } \\
\text { alveolata } \\
\text { hummock }\end{array}$ & \\
\hline & S. alveolata / silt / shells & 0.6 & $\begin{array}{l}\text { S. alveolata } \\
\text { mound }\end{array}$ & \\
\hline & S. alveolata & 0.7 & $\begin{array}{l}\text { S. alveolata } \\
\text { platform }\end{array}$ & \\
\hline
\end{tabular}

Table 1. Ecological description of the georeferenced photoquadrats $\left(N=303,0.5 \times 0.5 \mathrm{~m}^{2}\right)$ from which the abundance of Sabellaria alveolata open tubes was retrieved, as a proxy for the honeycomb worm reef state. 
Table 2. Spectral sensitivity (in $\mathrm{nm}$ ) of the airborne optical cameras (UltraCam-Xp and UltraCam-XpWA provided with focal lengths of 33 and $23 \mathrm{~mm}$, respectively).

\begin{tabular}{|c|c|c|c|}
\hline Blue & Green & Red & InfraRed \\
\hline $410-540$ & $480-630$ & $580-700$ & $690-1000$ \\
\hline
\end{tabular}

5

6

7 Table 3. Preliminary results of the performance (coefficient of determination, $R^{2}$ ) of three 8 regression models predicting the validation dataset of Sabellaria alveolata abundance $(N=$ 9 101), in respect to the spectral combination inputs.

10

\begin{tabular}{|c|c|c|c|}
\hline Spectral datasets & Ordinary Least Squares & $\begin{array}{c}\text { Generalized } \\
\text { Linear Model } \\
\text { (Poisson) }\end{array}$ & $\begin{array}{c}\text { Artificial Neural } \\
\text { Network } \\
\text { (3 neurons) }\end{array}$ \\
\hline RGB & 0.66 & 0.57 & 0.69 \\
\hline IRRG & 0.65 & 0.36 & 0.70 \\
\hline RGB+IRRG & 0.63 & 0.37 & 0.70 \\
\hline
\end{tabular}

